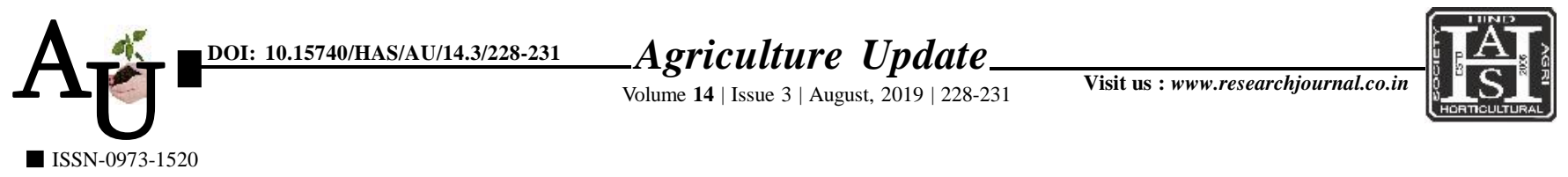

\title{
Research Article: Knowledge of home science technologies by the tribal women
}

A. D. Sangle, S. U. Mokhale, P. J. Kadu and A. S. Ade

Article Chronicle: Received : 09.06.2019;

Revised :

08.07.2019;

Accepted :

18.07.2019

KeY Words:

Knowledge, Home

science, Technology,

Tribal, Women

Farmers, Respondent

Author for correspondence :

\section{S.U. Mokhale}

Department of Extension

Education, Shri Shivaji

Agriculture College,

Amravati (M.S.) India

Email: shekharmokhale

17@gmail.com

See end of the article for

authors' affiliations
SUMMARY : The present study on knowledge of home science technologies by the tribal women" was undertaken in Dharni taluka of Amravati district with sample size of the 80 respondents. The data were collected from personal, socio-economic, communicational and psychological characteristics of respondents, knowledge about home science technologies was studied with the help of pre-structure interview schedule. Findings revealed that Majority 52.50 per cent of the respondents belonged to medium age group i.e. between 26 to 51 years, majority of the respondents 33.75 per cent were illiterate level, large proportion of respondents 46.25 per cent had marginal land holding, majority 61.25 per cent respondents were having medium level farming experience, more than half of the respondents 52.50 per cent having annual income between 22,000 to 48,000 , majority of the respondents 78.75 per cent had belonged to medium category of social participation, majority of the respondents 53.75 per cent of the respondents have medium level of extension contact and majority of the respondent 66.25 per cent had medium level of source of information. In case of knowledge about home science technologies majority of the respondents 88.75 per cent having medium level of knowledge about home science technologies. In case of home science technologies wise knowledge, great majority of respondents had knowledge about home science technologies viz., majority 100.00 per cent respondents have knowledge about information about this tool, followed by 100.00 per cent respondents have knowledge about the benefits of these implements. Findings of relational analysis revealed that age, education and source of information are positively and highly significant with knowledge of home science technology at 0.01 level of probability. Farming experience and annual income are significantly correlated with knowledge about home science technology at 0.05 level of probability. Whereas, land holding, extension contact, social participation were negatively non-significantly correlated with knowledge about home science technology at 0.05 level of probabilit.

How to cite this article : Sangle, A.D., Mokhale, S.U., Kadu, P. J. and Ade, A.S. (2019). Knowledge of home science technologies by the tribal women. Agric. Update, 14(3): 228-231; DOI : 10.15740/HAS/AU/14.3/228231. Copyright@ 2019: Hind Agri-Horticultural Society. 